\title{
A Qualitative Research on Active Learning Practices in Pre-school Education
}

\author{
Serpil Pekdoğan ${ }^{1}$, Mehmet Kanak ${ }^{2}$ \\ ${ }^{1}$ Department of Preschool Education, Faculty of Education, Amasya University, Turkey \\ ${ }^{2}$ Department of Guidance and Psychological Counseling, Faculty of Education, Cumhuriyet University, Turkey \\ Correspondence: Serpil Pekdoğan, Department of Preschool Education, Faculty of Education, Amasya University, \\ Turkey.
}

Received: July 4, 2016

Accepted: July 19, 2016

Online Published: August 23, 2016

doi:10.11114/jets.v4i9.1713

URL: http://dx.doi.org/10.11114/jets.v4i9.1713

\begin{abstract}
In educational environments prepared based on the active learning method, children learn with interest and pleasure, doing and experiencing, and directly through their own experiences. Considering the contributions of the active learning method and the educational environments designed based on it to children's development, it can be said that determining pre-service pre-school teachers' views about this topic will create a difference in the progress of the education system from the traditional model to the modern model and, most importantly, in providing children with better learning experiences. Taking this idea as a basis, the present study aims to explore the use of active learning practices in pre-school education based on pre-service pre-school teachers' views. The research data were obtained via semi-structured interview form and analyzed through content analysis. 30 pre-service teachers attending the third grade at the department of pre-school education participated in the study. The research findings indicate that the pre-service teachers think with regard to active learning practices in pre-school education that active learning practices in which teachers guide and support children's learning and a lot of activity processes are offered in a balanced and holistic way should be carried out in well-equipped classrooms that provide children with an area of movement.
\end{abstract}

Keywords: pre-school, active learning, teacher, pre-service teacher, child

\section{Introduction}

Pre-school children have a natural tendency to discover and learn. As of the time they come into the world, they have an eagerness to discover and learn, actively discover their environments, and start to produce various ideas (Ministry of Education, 2013). Active learning process in which children are active and teachers are guiding has a positive influence on children's holistic development areas. Active learning refers to a learning process in which the learner bears the responsibility of the learning process, is provided with an opportunity to make decisions and to make self-regulation about various aspects of the learning process, and is forced to use his mental skills through complicated instructional tasks during learning (Açıkgöz, 2003). Active learning enables children to work actively throughout the process by teaching them to make decisions about their learning. Decision-making is associated with all aspects of the learning processes. All the children who are to make decisions are also the teachers of themselves. They make their own study plans and can determine their own activities and goals. They can monitor their own development processes. They can see what they have learned, what they have understood, what they have mistaken, and what they achieved. In the active learning process, they can give feedbacks, conduct study control processes, and perform necessary preparation and other similar works by themselves. In addition, they can decide how to carry out learning activities (Stern \& Huber, 1997).

Active learning is also defined as a process that involves activities allowing children to generate in-depth ideas and use these ideas (Michael, 2006). Pundak, Herscovitz, Shacham and Weizer-Biton, (2010) report that the active learning approach supports children's comprehension more than the traditional learning approach. In the active learning process, children find many things to do in accordance with their interests and goals and talk about them frequently. Therefore, active learning environments may seem disorderly to adults who want to see groups of children doing the same things at the same time, but a child's internal motivation may provide an effective organization for both himself and the classroom environment (Hohmann \& Weikart, 1995). 
The order of the classroom environment facilitates the active learning process (Lambert \& Balderstone, 2000). The arrangement of an effective active learning environment requires fulfilling the necessary conditions (Nist \& Holschuh, 2000). The educational environment is an environmental factor for children. Pre-school children need rich learning environments where they can learn through their own behaviors, move and perform actions, engage in creation and imagination, play with their friends, and display their products. These learning areas improve children's skills of constructing their own learning and taking responsibility for learning (Smith, Cowie \& Blades, 2005).

A child's healthy development requires him to be in a stimulus-rich environment and necessitates offering him new learning opportunities. These kinds of positive experiences help the child develop positive attitudes towards school, learning, and his own skills. Learning centers constitute an important part of the educational environment in pre-school education. Learning centers are playgrounds that are prepared in accordance with the acquisitions and indicators that children are expected to gain through the activities contained in the daily course of education, incorporate different materials, and differ from one another with their different features. Block, book, music, science, and drama centers are always needed in pre-school education institutions. The teacher prepares learning centers based on children's interests, needs, and individual characteristics and the flow of education on the relevant specific day (Ministry of Education, 2013).

Active learning environments need to be supported by a good curriculum. Hendrick (1991) states that pre-school education curricula have to provide children with various learning experiences and be offered in a well-planned environment. These curricula aim to equip children with certain skills in such fields as science, mathematics, and reading. In this way, it is intended to improve every child's potential to the highest level. That requires arranging educational environments in a way that allows children to experience by themselves and participate actively (Ministry of Education, 2013). These kinds of curricula and educational environments are based on the activities that support children's characteristics such as establishing an effective communication with one another and adults, gaining independence and taking responsibility the materials that involve a lot of areas of interest, and the activities that they choose among many activities. The practices putting the child at the center emphasize the effectiveness of active learning environment, which supports the child's growth and development (Egertson, 1987).

Stephen, Ellis and Martlew (2010), concluded that active learning practices in the pre-school period accomplish their goals with well-structured curricula and effective learning environments. According to Demirtaş and Sucuoğlu (2009), group activities involving active learning carried out in the early childhood period have a positive effect on children's individual learning and group work, capability to produce more alternatives, and decision-making skills. Brain research shows that the children learning actively in a stimulus-rich environment have better problem-solving skills and learning capacity (French \& Murphy, 2005; Bruce, 2004).

According to Moke \& Shermis (1996), leading a successful and happy life requires being active learners. They also state that rapid change of technology in today's world requires children to acquire new skills and use them in the daily life. In educational environments prepared based on the active learning method, children learn with interest and pleasure, doing and experiencing, and directly through their own experiences. As stated by Vygotsky, the learning experiences children personally go through in stimulus-rich environments especially in the pre-school period make important contributions to their cognitive development. Considering the contributions of the active learning method and the educational environments designed based on it to children's development, it can be said that determining pre-service pre-school teachers' views about this topic will create a difference in the progress of the education system from the traditional model to the modern model and, most importantly, in providing children with better learning experiences.

\section{Method}

\subsection{Research Design}

This is a qualitative research in which survey model is used as it aims to explore the use of active learning practices in pre-school education based on pre-service pre-school teachers' views. Case study, which is a qualitative research method, is employed. Case study is a research design which is used in a lot of areas (e.g. evaluation processes) and in which the researcher makes an in-depth analysis of a situation, event, program, action, or process or deeply analyzes one or more individuals (Stake, 1995; Yin, 2009). The results of qualitative research are important in that they provide an insight into the topic though they cannot be generalized for the entire universe. In the present study in which the qualitative research method was employed, semi-structured interview was used as it helps to reveal complex personal and emotional problems, allows obtaining the requested information in full and depth, provides an opportunity to give instant feedbacks to responses, has a flexibility to adapt to various and suddenly changeable conditions, offers freedom to change the number and order of questions, and so on (Ekiz, 2003; Çepni, 2005; Yıldırım \& Şimşek, 2006; Karasar, 2007). 


\subsection{Participant}

The study group consists of 30 students attending the department of pre-school education at a faculty of education. Of the participants, $80 \%$ (24 students) are female while 20\% (6 students) are male. In qualitative research, sample selection is clearly associated with the characteristic of the research problem and the sources possessed by the researcher. Criterion sampling, which is a purposeful sampling method, is employed in the present study. Purposeful sampling methods allow in-depth analysis of situations that are common and considered to contain rich knowledge (Yildırım \& Şimşek, 2005).

\subsection{Instruments}

In the data collection process, the literature was reviewed first in order to provide a theoretical framework. Then a semi-structured interview form was created by the researchers for data collection. Semi-structured interview is a high-quality approach that eliminates the disadvantages of structured and unstructured interviews, but makes use of their advantages. In this kind of interview, the interviewer asks the questions he has prepared about the topic to participants systematically, but gives them enough freedom to enter into the details of the issue (Altunışık et al. 2001; Türnüklü, 2000).The created interview form was presented to the experts so that they would evaluate its suitability and adequacy for the topic. The prepared questions were reviewed and re-arranged based on the feedbacks provided by the experts. After the prepared interview forms were administered to two students, an expert to be asked to re-examine the obtained answers and check whether they were clear and understandable and included the topic researched. After that, an attempt was made to determine the validity of the question items. As is known, internal validity in qualitative research is about whether the researcher can really measure the data he intends to measure through the tool or method he is using or not (Yıldırım \& Şimşek, 2005). After the validity of the question items was ensured and necessary permissions were obtained, the interview forms were administered to the students within the scope of the main study.

The following questions were asked to the pre-service teachers;

1. How should a classroom environment supporting the active learning process be prepared?

2. What kind of a position should the teacher have in the educational practices taking the active learning process as a basis?

3. What kinds of activities are to be carried out to support the active learning process?

\subsection{Data Analysis}

Expert opinion was taken to ensure research validity, the validity of data collection, and the meaningfulness and coherence of the data. Reliability, on the other hand, indicates the repeatability of research results in qualitative research. It is tested in two ways: external validity and internal validity. While external reliability refers to the same coder's coding the same text in the same way at different times, internal reliability refers to different coders' coding the same text in the same way (Bilgin, 2006).

Four interviews that were randomly chosen from the semi-structured interviews were independently examined by one researcher and one expert for the formation of theme and category lists. Level of agreement was investigated through comparison of the created two lists. It was found to be $90 \%$. The themes on which there was an agreement were left as they were. The themes on which there was a disagreement, on the other hand, were discussed and rearranged.

The data obtained through semi-structured interview form were subjected to descriptive analysis and content analysis. Descriptive analysis involves summarizing and interpreting the obtained data based on pre-determined themes, frequently using direct quotations to manifest the interviewed individuals' views in a striking way, and interpreting the obtained results within the framework of cause and effect relationships (Yıldırım \& Şimşek, 2005). Descriptive analysis was made in three activity stages (data reduction, presentation of data, inference and verification) (Türnüklü, 2010). During the presentation of data, the criteria of being striking (distinctive opinion), being explanatory (relevance to the theme), variety, and being extreme were taken into consideration in the selection of the quotations (Miles \& Huberman, 1994). The data obtained from the forms were transferred to the electronic environment first. Then they were read several times, and codes were created. After that, the themes to yield the main research findings were formed based on the codes. Descriptive and content analyses were made based on them. Mostly, inter-coder consistency is calculated to determine reliability in content analysis. After the transcriptions of the interviews were formed, the interview coding key was created based on the interview questions. To identify the reliability of the interview coding key, the interview transcription forms of two participants were randomly chosen, reproduced, and independently evaluated by the researchers based on the interview coding key. This evaluation involved marking the choice on the interview coding key that was deemed consistent with the interviewee's view. To determine the consistency of the markings on the interview coding key, the responses to each question were examined one by one and compared. The interview coding key was finalized after that. The researchers, independently of each other, read the interview transcription forms of all the 
participants and marked the choices on the interview coding key that were consistent with the participants' responses. Based on such marking by the researchers, "Agreement" or "Disagreement" was marked. "Agreement" was marked when the researchers marked the same choice for a question whereas "Disagreement" was marked when they marked different choices for a question. To determine the reliability of content analysis, the formula of agreement percentage was used. Agreement percentage was calculated based on the following formula: "Reliability=Agreement/(Agreement + Disagreement) x 100" (Miles \& Huberman, 1994). According to Yıldırım and Şimşek (2005), reliability is ensured when agreement percentage is found to be not less than $70 \%$ in the calculation of reliability. Based on this formula, the agreement percentages in the coding operations of the present study were found to be as follows: the first question: 0.82; the second question: 0.84; the third question: 0.90; general agreement percentage for all the questions: 0.85 (Yıldırım \& Şimşek, 2005). The findings indicate that the questions are reliable.

The content analysis process involves the stages of coding and categorizing data, finding themes, organizing and defining the data based on the codes and themes, and interpreting the findings (Yildırım \& Şimşek, 2005).Then the frequency and percentage values of the obtained qualitative data were determined, and the research findings were interpreted based on direct quotations from the striking opinions of the interviewed students.

Forming the Codes: Coding was done by considering the research questions and the concepts obtained from the data. The codes in parentheses were created by the researchers. For example, the $1^{\text {st }}$ person indicates the student's code (S29).

Forming the Themes: The themes were formed by bringing together similar codes.

\section{Results}

Semi-structured interviews were carried out with 30 students studying pre-school education. After the interviews, the findings obtained from the answers given by the students were categorized in themes.

1. What are the pre-service teachers' views about how a classroom environment involving active learning should be prepared?

2. What are the pre-service teachers' views about the position of the teacher in active learning practices?

3. What are the pre-service teachers' views about the kinds of activities to be carried out in active learning practices?

The findings are tabulated below.

Table 1. The pre-service teachers' views about what should be paid attention to while a classroom environment involving active learning is being prepared

\begin{tabular}{|c|c|c|}
\hline Themes & $\mathrm{f}$ & $\%$ \\
\hline \multicolumn{3}{|l|}{ About Children } \\
\hline Children's interests and needs are important & 39 & 10.3 \\
\hline The number of children should be considered & 35 & 9.2 \\
\hline \multicolumn{3}{|l|}{ About the Classroom Environment } \\
\hline The size of the classroom is important & 49 & 13.5 \\
\hline $\begin{array}{l}\text { The materials in the classroom should be simple and } \\
\text { restful }\end{array}$ & 20 & 5.3 \\
\hline The classroom should be lighted & 15 & 3.9 \\
\hline $\begin{array}{l}\text { Necessary safety measures should be taken in the } \\
\text { classroom }\end{array}$ & 36 & 9.5 \\
\hline $\begin{array}{l}\text { Learning centers should be changeable depending on } \\
\text { needs }\end{array}$ & 43 & 11.4 \\
\hline $\begin{array}{l}\text { Learning centers should be situated in different areas } \\
\text { depending on their characteristics }\end{array}$ & 48 & 12.7 \\
\hline $\begin{array}{l}\text { The materials contained in learning centers should be } \\
\text { natural, and waste materials should be used }\end{array}$ & 26 & 6.8 \\
\hline $\begin{array}{l}\text { Children should always have an easy access to the } \\
\text { materials in the classroom }\end{array}$ & 42 & 11.1 \\
\hline $\begin{array}{l}\text { There should be sufficient number of materials for } \\
\text { children }\end{array}$ & 24 & 6.3 \\
\hline Total & 377 & 100 \\
\hline
\end{tabular}

When the pre-service teachers' views in the table concerning what a classroom in which the active learning method is implemented should be like are analyzed, it is seen that the size of the classroom is focused on most. In this matter, the following pre-service teacher views highlight the importance of the classroom size for practices: "If the classroom was large, I would form corners of interest, which are learning centers, in a way allowing children to act easily" (S3) and "A large classroom will arouse the curiosity of children and make them actively participate in activities to satisfy their curiosity. Largeness of classrooms provides children with convenience in terms of movement and use of materials"(S11). The pre-service teachers also paid attention to children's interests and needs, the number of children, the position of 
learning centers, the materials contained in the learning centers, and the appropriateness of materials for children. Some of the expressed views are as follows: "If I were to arrange a classroom taking active learning practices as a basis, I would design a classroom based on children's interests and needs and the number of children in the classroom. If the classroom was small, I would create learning centers based on needs and change them from time to time. I would put materials in areas accessible to children" (S1);"It should be a classroom that activates mental processes and supports all the development areas. It should be lighted and safe. Its wall colors should be light. A spacious classroom will make children more comfortable. Learning centers should be situated in such a way that they are harmonious with one another, but do not affect one another. For example, there should not be a music center next to a book center. Science center should contain materials such as stones, sea shells, leaves, and live plants. Other centers should contain waste and natural materials" (S25); "The classrooms taking active learning practices as a basis should be arranged based on children's interests and needs. They should support children's creativity and allow them to work in cooperation. For example, materials to be used in science activities can be recyclable and reusable materials such as paper and plastic bottle. There should be sufficient number of each material so that every child can use every material. Material diversity is important. Permanent learning can be achieved if children work with materials appealing to different senses" (S18).

Table 2. Pre-service teachers' views about the teacher's position in active learning practices

\begin{tabular}{lll}
\hline Themes & & 7.8 \\
\hline $\begin{array}{l}\text { About the Teacher's Role } \\
\text { The teacher should be passive }\end{array}$ & 8 & 40.8 \\
$\begin{array}{l}\text { The teacher should be guiding } \\
\text { The teacher should be a good }\end{array}$ & 42 & 14.6 \\
$\begin{array}{l}\text { observer } \\
\begin{array}{l}\text { The teacher should prepare an } \\
\text { environment supporting children's }\end{array}\end{array}$ & 36.8 \\
$\begin{array}{l}\text { learning } \\
\text { Total }\end{array}$ & \\
\hline
\end{tabular}

When the pre-service teachers' views are analyzed, it is seen that most of them argued that the teacher should be guiding in active learning practices. This view is followed by preparing an environment, being an observer, and being passive respectively. The pre-service teacher views in this matter are as follows: "The teacher should only guide. He should not restrict children. For example, if he says, 'No! Science center is prohibited. Don't touch the tools there', children's active participation in the process will be blocked" (S29); "The teacher should only observe children and activate their curiosity" (S30);"The teacher should be guiding in the active learning process. The educator should attract the children's attention and guide them while activities are being conducted or materials are being selected" (S26); "The teacher should prepare the classroom in active learning practices. In this way, children can learn by doing and experiencing and through their own experiences" (S21); "The teacher should have a passive position. Materials and activities should be chosen and determined by children so that permanent learning is achieved" (S13); "No matter how withdrawn the educator is in terms of intervention, he should guide and intervene in when required" (S22).

Table 3. The pre-service teachers' views about the kinds of activities to be carried out in active learning practices

\begin{tabular}{lll}
\hline Themes & $\mathrm{f}$ & $\%$ \\
\hline $\begin{array}{l}\text { About the Kinds of Activities } \\
\text { Science activities should be } 27\end{array}$ & 33.0 \\
$\begin{array}{l}\text { carried out } \\
\begin{array}{l}\text { Play-drama activities should be } 35 \\
\text { carried out }\end{array}\end{array}$ \\
$\begin{array}{l}\text { About the Way Activities Should } \\
\text { Be Carried Out }\end{array}$ & 42.7 \\
$\begin{array}{l}\text { Holistic activities should be } 20 \\
\text { carried out in a balanced way } \\
\text { Total }\end{array}$ & 82 & 24.3 \\
\hline
\end{tabular}

As it is seen in the Table 3, the pre-service teachers mostly stated play-drama activities as an effective method in the active learning process. The pre-service teacher views in this matter are as follows:"Play is for children. They participate in the process via plays. They learn the life through plays. Drama, on the other hand, gives them a chance to express their feelings and thoughts. Thus, play and drama activities are the most important activities to be carried out for children's permanent learning"(S11); "Play exists at every corner of the child's life. He becomes socialized through play, and his communication skills develop through play. He is active in every part of play. He learns a lot of things in play by performing as a doctor, teacher, nurse, and so on. Play is among the most appropriate activities for active learning"(S24);"In active learning, the child always acts, tries, and asks questions. So, science activities play an important role in active learning. Individual or small-group activities can be carried out through experiments and explorations by use of natural materials" (S26); "In the learning process, experiments attract children's attention a lot. 
Especially the experiments conducted through formation of small groups provides permanent learning" (S28); and "Active learning will be made permanent by an educational process in which an educational environment that can improve children's creativity, make them search and question, and arouse their curiosity is prepared and a lot of activities are offered in a holistic way"(S16).

\section{Discussion}

This study deal with the pre-service pre-school teachers' views about the use of active learning practices in pre-school education. The findings obtained through semi-structured interviews with 30 students are discussed here. The literature does not contain this kind of a research about pre-school children. The findings of the present study are discussed in the light of the related literature and researches.

The pre-service teachers expressed important views about classroom size and the functionality of learning centers in the classroom for effective active learning practices. They also delivered their views about the importance of children's interests and needs for active learning practices, the physical (i.e. equipment)characteristics of the classroom, and the sufficiency, usage, and accessibility of the materials in the classroom. One of the most important points to consider in the active learning process is children's interests and needs. This is because; active learning process supports the child's learning on his own and takes process evaluation as basis. Learning domains and materials have a big importance for this approach, which surpasses traditional methods and takes learning as a development process, to maintain its vitality for especially pre-school children. This is because; children always tend to discover in curiosity and creativity. One of the prerequisites to support this process in the best way is having safe and peaceful educational environments that are equipped with good materials and provide freedom of movement. Silberman (1996) states that classroom conditions are important in active learning, and classroom should be arranged in a way allowing the teacher and children to communicate comfortably. The classroom arrangement should allow children to use materials actively (Huber, 2000). Avc1 (2001) argues that paying attention to individuals' interests and needs besides the physical characteristics of the classroom will make the active learning process functional. The students also expressed similar views in this matter. The effects of active learning environment on communication and active participation process have been explored by other researchers at different educational levels as well. DeWayne (1990) concluded that the highest level of communication and interaction is achieved with the active learning environment in the primary education mathematics course. Lena et al. (2001) found out that university students' motivation and communication levels are raised in the active learning environment. The above-mentioned research findings and related literature imply that active learning environment has a positive effect on communication and active participation process at every educational level and are consistent with the findings of the present study.

In the active learning process, there is a sharing-based and cooperative relationship between the learner and the teacher in which the teacher is guiding and improving the learner's skills (Johnson, Johnson \& Smith, 1991). Another important point in active learning is the role played by the teacher. In the active learning model, the teacher arranges the learning environment in advance. He determines what he will do before the educational process. The teacher who prepares and plans the lesson goes on with the role of a guide. He starts the activity by informing the children, offers the related materials, and exposes them to a problem situation (Pekin, 2000). Plourde and Alawiye (2003) reported that teachers employing the active learning process are more successful. Stephen, Ellis and Martlew (2010) determined that the teachers lecturing in an environment constructed based on the active learning process are more successful. In addition, as active learning is theoretically based on constructivism and cognitivism, the learner should be provided with an opportunity to construct his knowledge (Phillips, 1995). In the present study, a lot of pre-service teachers stated that the teacher should be a good guide in the educational process and organize the educational environment. They also indicated that the teacher should be a good observer and passive during in-class practices. These findings are consistent with the related literature.

Active learning supports creative thinking as well. Learning environments should be arranged in a way improving creative thinking. Methods such as drama, problem-solving, and brainstorming make the active learning process functional and support creative thinking (Bulut, 1999). These kinds of practices, which put the child at the center, support the child's growth and development and contribute to the active learning process (Egerston, 1987). Science, play, music, etc. activities carried out in accordance with children's ages and development levels during pre-school education support their discovering and learning processes (Whitebread, 1997). In this way, children participate in the active learning process by interacting with their environments rather than remaining passive during learning. Moreover, children should actively be included in speaking, painting, drama, project, and field trip activities. These activities should be used together. These kinds of learning processes will contribute to children's social and cognitive learning (Katz, 2003). In the present study, the pre-service teachers stated that making children mostly engage in play-drama and science activities and offering these activities in a balanced and holistic way will support the active learning process. Various studies (Gibson \& Chase, 2002; Harton et al., 2002; Kalem \& Fer, 2003; Aydede \& Kesercioğlu, 2012) reported 
that the educational environments and curricula prepared by taking the active learning process as basis have a positive influence on learning.

The findings of this study show that active learning practices in which the teacher guides and supports children's learning and a lot of activity processes are offered in a balanced and holistic way should be carried out in well-equipped classrooms that provide children with an area of movement. In the light of these findings, qualitative research taking active learning practices as a basis can be conducted on different sample groups. Experimental studies taking active learning practices for pre-school children as basis can be conducted. Finally, relationships between children's active learning processes and different variables can be explored, thereby making a contribution to the literature.

\section{References}

Açıkgöz, K. Ü. (2003). Aktif öğrenme. İzmir: Eğitim Dünyası.

Altunışık, R., Coşkun, R., Bayraktaroğlu, S., \& Yıldırım, E. (2005). Sosyal bilimlerde araştırma yöntemleri: SPSS uygulamall. Adapazarı: Sakarya.

Avcı, S. (2001). Aktif öğrenme. Retrived: 27.06.2016 from, http://www.ogretmenlersitesi.com.

Aydede, M. N., \& Kesercioğlu, T. (2012). Aktif öğrenme uygulamalarının öğrencilerin kendi kendine öğrenme becerilerine etkisi. Hacettepe Üniversitesi Ĕ̈itim Fakültesi Dergisi, 43, 37-49.

Bilgin, N. (2006). Sosyal bilimlerde içerik analizi: Teknikler ve örnek çalışmalar. Ankara: Siyasal.

Bruce, T. (2004). Developing learning in early childhood. London: Paul Chapman.

Bulut, Ş. (1999). Çocukların yaratıcı gelişmelerine yardımcıolmak. Yaşadıkça Eğitim Dergisi, 61(6), 14-21.

Çepni, S. (2005). Araştırma ve proje çalışmalarına giriş. Trabzon: Üçyol Kültür Merkezi.

Demirtaş, V. Y., \& Sucuoğlu, H. (2009). In the early childhood period children's decision-making processes. ProcediaSocial and Behavioral Sciences, 1(1), 2317-2326. http://dx.doi.org/10.1016/j.sbspro.2009.01.407

DeWayne, M. (1991). The effect of two small-group models of active learning on sixth-grade mathematics achievement. Dissertation Abstract International, 51(8), 249.

Egertson, H. S. (1987). The shifting kindergarten curriculum.Urbana, IL: ERIC Clearinghouse. ED293630.

Ekiz, D. (2003). Ĕ̆itimde araştırma yöntem ve metotlarına giriş. Ankara: Anı

French, G., \& Murphy, P. (2005). Once in a lifetime: Early childhood care and education for children from birth to three. Dublin: Barnardos.

Gibson, H. L., \& Chase, C. (2002). Longitudinal impact of an inquiry-based science program on middle school students' attitudes toward science. Science Education, 86(5), 693-705. http://dx.doi.org/10.1002/sce.10039

Harton, H. C., Richardson, D. S., Barreras, R. E., Rocloff, M. J., \& Latane, B. (2002). Focused interactive learning: A tool for active class discussion. Teaching of Psychology, 29(1), 10-15. http://dx.doi.org/10.1207/S15328023TOP2901_03

Hendrick, J. (1991). Total learning developmental curriculum for the young child. New York: Macmilllian.

Hohmann, M., \& Weikart, D. P. (1995). Educating young children: Active learning practices for preschool and child care programs. Ypsilanti, MI: High/Scope Press.

Huber, L. K. (2000). Promoting multicultural awareness through dramatic play centers. Early Childhood Education Journal, 27(5), 234-239.

Johnson, D. W., Johnson, R. T., \& Smith, K. A. (1991). Cooperative learning: Increasing college faculty instructional productivity. ASHE-ERIC Report on Higher Education. Washington, DC: The George Washington University.

Kalem, S., \& Fer, S. (2003). Aktif öğrenme modeliyle oluşturulan öğrenme ortamının öğrenme, öğretme ve iletişim sürecine etkisi. Kuram ve Uygulamada Ë̆itim Bilimleri, 3(2), 433-461.

Katz, L. (2003). State of the art in early childhood education 2003. ERIC Document No. 475, 599.

Lambert, D., \& Balderstone, D. (2000).Learning to teach geography in the secondary school: A companion to school experience. London and New York: Routledge/Falmer.

Lena, A. N., Bergendahl, C., Stenlund, P., \& Tibell, T. (2001). An open laboratory experiment, a method for active learning: Biochemistry education for millennium, Dissertation Abstract International, 53(7), 846-A, (E29-E34).

Michael, J. (2006). Where's the evidence that active learning works? The America Physiological Society, 30, $159-167$. 
http://dx.doi.org/10.1152/advan.00053.2006

Miles, M. B., \& Huberman, A. M. (1994).Qualitative Data Analysis (2nd edition).Thousand Oaks, CA: Sage.

Ministry of Education (2013). Okul öncesi eğitim programı (Preschool Education Program). Ankara: Milli Eğitim Basımevi.

Moke, S., \& Shermis, M. (1996).The active learner: Help your child learn by doing. The successful learner series. Bloomington: Grayson Bernard Publishers.

Nist, S. L., \& Holschuh, J. (2000). Active learning strategies for college success. London: Allyn and Bacon.

Pekin, H. (2000). The effect of active interactive learning approach in primary education $5^{\text {th }}$ grade mathematics education on student success. Master's Thesis, Uludağ University Institute of Social Sciences, Bursa.

Phillips, D. C. (1995). The many face of constructivism. Educational researcher, 24(4), 13-17.

Plourde, L. A., \& Alawiye, O. (2003). Constructivism and elementary pre-service science teacher preparation: knowledge to application. College Student Journal, 37(3), 334-342.

Pundak, D., Herscovitz, O., Shacham, M., \& Weizer-Biton, R. (2009). Instructors' attitudes toward active learning. Interdisciplinary Journal of E- Learning and Learning Objects, 5, 215-232.

Silberman, M. (1996).Active Learning: 101 strategies to teach any subject. Pearson Higher Education.

Smith, P. K., Cowie, H., \& Blades, M. (2005). Understanding children's development. USA: Blackwell.

Stake, R. (1995). The art of case study research. Thousand Oaks, CA: Sage.

Stephen, C., Ellis, J., \& Martlew, J. (2010). Taking active learning into the primary school: A matter of new practices? International Journal of Early Years Education, 18(4), 315-329. http://dx.doi.org/10.1080/09669760.2010.531916

Stern, D., \& Huber, G. (1997). Active learning for students and teachers oecdr ports from eight countries. Germany: OECD.

Türnüklü, A. (2000). Eğitim bilim araştırmalarında etkin olarak kullanılabilecek nitel bir araştırma tekniği: Görüşme. Kuram ve Uygulamada Ĕ̈itim Yönetimi Dergisi, 6(4), 543-559.

Whitebread, D. (1997). Teaching and learning in the early years. London: Routledge.

Yıldırım, A., \& Şimşek, H. (2005). Sosyal bilimlerde nitel araştırma yöntemleri. Ankara: Seçkin.

Yin, R. K. (2009). Case study research.Design and Methods. Thousand Oaks, CA: Sage.

\section{$(\infty)$ EY}

This work is licensed under a Creative Commons Attribution 3.0 License. 